\title{
Monitoring mechanisms and financial distress of public listed companies in Malaysia
}

\author{
Soheil Kazemian \\ Universiti Teknologi $M A R A$ \\ Malaysia \\ Soheilkazemian@salam.uitm.edu.my \\ Noor Azura Ahmad Shauri \\ Kolej universiti Poly-Tech MARA \\ Malaysia \\ zueraichi@yahoo.com
}

Zuraidah Mohd Sanusi

Universiti Teknologi MARA

Malaysia

zuraidahms@salam.uitm.edu.my

\author{
Amrizah Kamaluddin \\ Universiti Teknologi MARA \\ Malaysia \\ amrizab@salam.uitm.edu.my
}

\author{
Shuhaida Mohamed Shuhidan \\ Universiti Teknologi MARA \\ Malaysia \\ shubaida6704@salam.uitm.edu.my
}

Abstract. This study examines the relationships between financial distress and financial ratio (liquidity, leverage, profitability, firm's performance, and dividend) among public listed companies, using the Altman Z-Score to determine the financial distress levels among public listed companies in Malaysia. Five-year data has been collected (2010 to 2014) from the annual financial statements and from Data Stream of public listed companies in Malaysia. The findings indicate significant relationships between liquidity, leverage, profitability, firm's performance, and dividend with the financial distress levels among the of International 
Corporate Governance (MCCG) in 2012 on financial distress levels. The results suggest that only liquidity and firm's performance have stronger effects on financial distress levels in two years after MCCG implementation. This indicates that after the implementation of the Code, liquidity and firms' performance ratios had strong and significant effect on financial distress levels. Overall, this study could help investors, creditors as well as external regulators in monitoring companies from being classified as financially distressed companies.

Keywords: corporate governance, financial ratios, financial distress, Malaysia, monitoring mechanism

JEL Classification: B26, G15, M21, P34

\section{INTRODUCTION}

Financial distress can be defined as "a condition where financial obligations are not met or are met with difficulty" by a firm (Wu, Liang, \& Yang, 2008). Chan \& Chen (1991) defined financially distressed firms as those having poor performance, inefficient producers, and also those likely to have high financial leverage and cash flow problems due to which firms lose their market value. They are marginal in the sense that their prices tend to be more sensitive to changes in the economy, and are less likely to survive adverse economic conditions. Due to this, investors demand a premium for holding such risky stocks and expect to be rewarded for bearing the risk. Typically, financial distress of the above nature is measured by the probability of failure (Shumway, 2001).

Recently, financial distress has become a famous topic in finance and financial health of firms as a crucial indicator for interested users to know more about company's performance. Many stakeholders such as creditors, suppliers, investors, customers as well as employees are reluctant to deal with financially distressed firms (Cornell \& Shapiro, 1987). According to Beaver (1966) and Betker (1997), financial distress plays a significant role in a firm's operations and profitability through its cost implications, such as administrative and legal costs associated with the bankruptcy process (i.e., direct financial distress costs) or increased costs for debt service and supplies (i.e., indirect financial distress costs). These costs may reduce the value of the company and thus it is important to determine the financial distress level among companies in Malaysia (Abdul Rahman et al., 2016).

Determining the financial level is important for investors and creditors so that to know whether a company is financially healthy. They can use this knowledge especially in their financial planning and take remedial actions to avoid potential bankruptcy costs. This is important to current investors, potential investors and also to stock market regulators. In other words, it could be used in developing an early warning system to either evade, or lessen the impeding failures. For example, bankers or creditors could use this information to assess potential borrowers or their potential credit risk. Information provided in financial statements is sufficient to discriminate and assess creditworthiness of large businesses (Belás et al, 2015).

Financially distressed firms face several issues of financial difficulty and poor financial performance. Financial distress has become a global problem that needs high-quality monitoring and certain mechanisms to prevent it from affecting various stakeholders such as shareholders and creditors. Liquidity, leverage, profitability, and firm's performance take the leading role in assessment of failing companies probability (Becchetti \& Sierra, 2003; Ong, Yap, \& Khong, 2011; Zeli, 2014). In addition to the basic areas affecting financial distress, dividend changes have also long been viewed as a signal of both current and expected 
future firm prospects. Dividends work as a signal of future growth opportunities and this is consistent with the findings of Abreu and Gulamhussen (2013), Bessler and Nohel (1996), and Filbeck and Mullineaux (1993).

In Malaysia, the stock market regulator is Bursa Malaysia, which also deals with financially distressed companies. Bursa Malaysia, previously known as the Stock Exchange of Malaysia, is an exchange holding company approved under Section 15 of the Capital Markets and Services Act 2007, operating under the Securities Commission. Strict requirements were issued by Bursa Malaysia to all public listed companies in 2011 to monitor the quality of markets under Bursa Malaysia. In order to remain listed on the main market, all public listed companies need to fulfill two key requirements. The first requirement is that public listed companies should have continuous profit after tax for three to five full financial years with an aggregate of at least RM 20 million. The second requirement is that public listed companies should have profit after tax of at least RM 6 million in the most recent financial years. Companies that fail to maintain their quality will be listed as financially difficult companies according to Practice Notes 4 and 17 (Mohamed Sadique, Roudaki, Clark, \& Alias, 2010). Bursa Malaysia introduced Practice Note No. 4/2001 (PN4) on 15 February 2001 and Practice Note No. 17/2005 (PN17) on 3 January 2005. PN17 was further amended on 5 May 2006 to improve the ways in which Bursa Malaysia deals with listed financially distressed companies.

During an economic crisis, Malaysian companies suffer from excessive leverage, lack of transparency, fragile financial structure, disclosure, and accountability (Rashidah Abdul \& Fairuzana Haneem Mohamed, 2006). Most of the companies in Malaysia have experienced downturns that negatively impacted their financial position. The best indicator of financial distress is leverage indicators because they measure external and internal financing combination and, above all, the basis of the financial pyramid or, in other words, they measure how many asset units are financed by one capital unit. Liquidity is commonly linked to financial distress because it reflects the extent to which a company is able to fulfill its obligations. Firms with low liquidity ratio have higher risk of default because of their potential inability to pay their liabilities (Kim-Soon, Mohammed, \& Agob, 2013). Profitability as well as firm's performance are also important indicators of financial distress; the profitability ratio will give measure of the final output.

In Malaysia, little empirical research has been done so far to assess the factors significant under financial distress. Lack of research on the factors that contribute to financial distress signifies that users do not have proper information about future prospects of a firm. Therefore, it is important to study the factors that are significant to financially distressed companies in Malaysia and thus provide a clearer picture in determining the significance of financial indicators while detecting financially distressed companies.

Therefore, this paper aims at identifying the indicators of financial distress through examining the relationships between "liquidity, leverage, profitability, firm performance and dividend" on one hand and financial distress levels on the other.

Based on these objectives, the rest of the paper proceeds as follows: The second section describes the background of monitoring mechanisms and financial distress. The third section describes the conceptual framework applied in this research, followed by the explanations about the methodology used for gathering and analyzing data. The fifth and sixth sections present the findings of the study and the discussion of these findings, respectively. Then, the seventh section draws an overall conclusion of the research. Finally, the last section discusses the directions for future research. 


\section{BACKGROUND OF MONITORING MECHANISMS AND FINANCIAL DISTRESS}

This section provides previous literature review that can serve as a basis for this study, and it is divided into two parts; section 2.1 discusses the financial ratios of financially distressed companies and section 2.2 explains the monitoring mechanisms.

\subsection{FINANCIAL RATIOS OF FINANCIALLY DISTRESSED COMPANIES}

In analyzing the financial statement, financial ratios are an important tool to evaluate a company's performance to find out the financial status of the company. Financial ratios are useful indicators to evaluate a firm's performance and financial situation (Kim-Soon et al., 2013). Profitability, liquidity and solvency, as well as the efficiency of management are important in determining corporate financial distresses as well as in the design and implementation of financial policies and investment (Mohammed, 1997). This is also supported by the researchers' view that financial ratios measuring size, liquidity, profitability, and leverage are likely to be important determinants of financial distress besides institutional and corporate governance factors (Bhattacharjee \& Han, 2014).

i. Liquidity

Liquidity is a measure of the extent to which a person or organization has cash to fulfill immediate and short-term obligations, or assets that can be quickly converted to do this. The financial liquidity ratios are the tools that are commonly used to measure financial performance (Courtis, 1978).

\section{ii. Leverage}

Companies that have higher leverage may have a higher risk of bankruptcy, if they do not make payments on their external financing to their creditors. If the company wishes to take another loan, creditors will make some measurements whether the company has too much borrowing and request the company to keep its debt within reasonable boundaries (Kazemian, Mohd-Sanusi, 2015).

iii. Profitability

Profitability will reflect the ability of the company to turn sales revenue into different types of income such as gross profit, net profit, operating profit, and expressed as a portion of each dollar of sales.

iv. Firm Performance

Evaluating the firm's performance is a powerful tool for decision makers especially investors and creditors. It is important for them to know the risk of the investment as well as the loan provided to the companies. Using financial ratios is a perfect tool to determine the financial performance of a company.

v. Dividend

According to Pandey (2001), dividend is defined as a portion of a company's net earnings that is distributed to the shareholders in proportion to their shareholdings in the company.

\subsection{MONITORING MECHANISMS}

The previous section reviewed all the relevant aspects of financial distress. This section focuses on the different dimensions of monitoring mechanisms and the possible solutions for preventing accruing financial distress through them.

i. Investors

The most important thing for investors is to know the bottom line in the financial statement. They need to know how much the company earns and how much reward it is able to pay them. In addition, they want to know more about information such as business outlook, future condition of the firm and its industry, projected growth rates of sales, earnings, and dividends (Baker \& Haslem, 1973). By having this 
kind of information, investors may know whether the company is on a growth trajectory or on a decline. Many researchers have found that in order to find out the reward for the investors, they need to look further into information on liquidity, leverage, profitability, performance of the company, as well as the dividend payout ratio. These kinds of information are important in order to know how much they will be rewarded in the form of dividend from the company in which they invest. Previous studies have found that liquidity is relevant to the investors of the company and it is priced into the expected returns (Amihud \& Mendelson, 1986, 1991).

The firm's size and level of liquidity explain a firm's decision to pay dividends to investors. Liquidity has the strongest contribution in making decisions to pay dividends and in fact, larger companies and liquid companies are likely to pay a higher amount of dividend and liquidity has the strongest contribution in explaining the decision of whether to pay dividends at all (Redding, 1997).

ii. Creditors

A creditor is a party (e.g., person, organization, company, or government) that has a claim on the services of a second party. According to Sullivan and Sheffrin (2003), a creditor is a person or institution to whom money is owed. Creditors, who are one of the capital providers to a company, rely on a company's financial condition to know where their money goes so that they can have deep insight about the financial risks of the company. Liquidity analysis focuses on the measure of the ability of the company to fulfill its obligation in having an eligibility term of less than one year. It is important for creditors (especially shortterm creditors) to know whether the company can repay their loan. Previous literature has highlighted the importance of analyzing financial statements using liquidity ratios as a monitoring mechanism for stakeholders (Costea \& Hostiuc, 2009).

iii. Regulatory bodies

Regulatory bodies are responsible for supervising and managing the securities industry in Malaysia such as Securities Commission, Bank Negara, and Bursa Malaysia. For example, Bursa Malaysia needs to make sure that all the companies especially public listed companies comply with all the regulations to remain listed in Bursa Malaysia. They act as an authority in assessing the ongoing concerns as well as the solvency of a company. One of the ways to make sure that companies in Malaysia are in compliance with laws and ethical values and to maintain an effective governance structure is by introducing the MCCG in 2012 which includes compulsory guidelines to all the public listed companies. Research found that the implementation of MCCG had a substantial effect on shareholders' wealth and increased the stock prices of a firm (Wahab, How, \& Verhoeven, 2007). Good governance of a company might reduce the probability of insolvency. This is also supported by Fich and Slezak (2008), who found that governance characteristics of distressed firms affect the probability of bankruptcy. Thus, it is important for a regulatory body to monitor the level of financial distress to prevent and protect from any financial failures using public funds.

\section{CONCEPTUAL FRAMEWORK}

Figure 1 covers the general framework of the current study. The main objective of this study is to examine the relationship between financial ratio (liquidity, leverage, profitability, and dividend policy) and the financial distress level among public listed companies in Malaysia. In addition to that, it may act as a monitoring mechanism to interested users such as investors, creditors, and external regulators, in helping them to determine the level of financial distress. Thus, it may help them in making decisions about the companies. 
First, this study covers the issue of liquidity as the main determinant to predict financial distress. For the second relationship, leverage is expected to have a positive relationship with financially distressed companies. Next relationship to be examined is whether a low level of profitability will increase the probability of financial distress. As for the last relationship, it is to find out whether a low level of dividend may indicate the prediction of financially distressed companies in Malaysia. All of the independent variables listed above are monitoring mechanisms and they are expected to act as early indicators to all users.

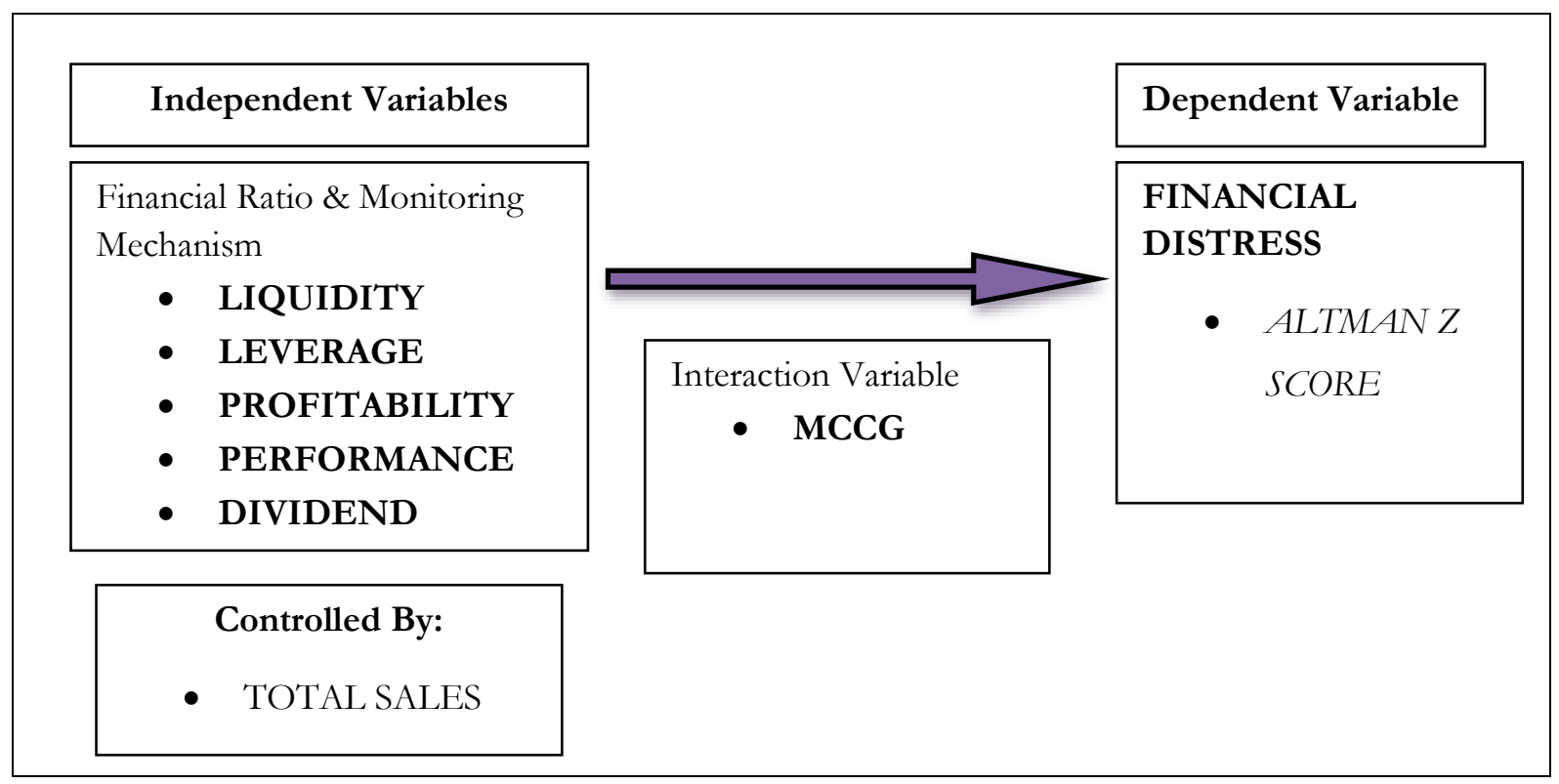

Figure 1. Conceptual Framework

\section{HYPOTHESIS DEVELOPMENT}

This study has primarily focused on financial indicators in detecting financial distress, which is important to the multiple roles of external agency mechanisms such as potential investors, current investors, creditors, as well as regulators as an early indication of financial distress. Six hypotheses are developed to be tested and to support the research objectives.

One of the important determinants in identifying financial distress among government linked companies in Malaysia is knowing the liquidity of the company (Ahmad Khaliq \& Md Yousuf Harun, 2014). The level of liquidity may indicate the financial distress level of the companies. Hence, based on the above arguments, the first hypothesis is developed as follows:

H1: Firms with lower liquidity would have a higher possibility of financial distress.

Firms which have high leverage may face a high risk of bankruptcy if they are unable to make payments on their external debt financing. According to Chan and Chen (1991), the leverage ratio is useful in determining the level of financial distress. Research done in Thailand, found that leverage has a negative effect on performance of companies for large firms in Thailand (Vithessonthi \& Tongurai, 2015). Based on the above arguments, the second hypothesis is developed as follows:

H2: Firms with higher leverage would have a higher possibility of financial distress.

According to Theodossiou et al. (1996), profitability is the factor that is highly involved in financial distress and it is agreed that financial failure leads to substantive weakening of the profitability of a company 
over time. Research by Geng, Bose, and Chen (2015) indicates that the risk of financial distress is high when profitability is low. A low profitability is a signal of the firm's incapacity to convert the revenue flow into profits. The higher the profitability, the lower the probability of financial distress.

Based on the above argument, the third hypothesis is developed as follows:

H3: Firms with lower profitability would have a higher possibility of financial distress.

Rumelt (1974) found out that he could identify the performance of single and dominant integrated firms using financial ratios as the measurement of company performance. The study found that a firm in single or related businesses had a better ratio of firm performance compared to a dominant vertically integrated firm. This is also supported by the research by Zeli (2014); poor company performance may increase the probability of a company turning into a financially distressed company in Italy. The poor performance of a company indicates that the company is unable to manage its fund, poor in accounting systems, poor in financial controls, and poor in productivity and profitability.

Based on the above argument, the fourth hypothesis is developed as follows:

H4: Firms with lower performance would have a higher possibility of financial distress.

The wealth of a company may be indicated by its dividend. This is because according to Farinha and Moreira (2007), a dividend would signal future profitability and earning quality of the company in the sense of earnings with a low degree of manipulation. Malombe (2011) studied the impact of the dividend policy on profitability of companies in Kenya and found that there is a positive relationship between dividend policy and profitability of companies but it is an insignificant relationship. In other words, companies with financial problems will tend to reduce the dividend payout ratio and lessen the dividend payment (Coffinet, Pop, \& Tiesset, 2013). Low dividend payment as well as low dividend payout may be affected by the financial health of the companies. Hence, based on the above arguments, the fourth hypothesis is developed as follows:

H5: Firms with a lower level of dividend would have a higher possibility of financial distress.

The recent changes in the best corporate governance practices by the Malaysian Institute of Corporate Governance (MICG) have strengthened some elements of the corporate governance codes. The revised Malaysian Code of Corporate Governance (MCCG) in 2012 focused on strengthening the board structure and the composition by recognising the role of directors as active and responsible fiduciaries (MCCG, 2012). Directors have the task of being effective stewards and guardians of a company in setting the strategic direction and managing the conduct of business. In fact, they also need to ensure that the company is in compliance with laws and ethical values, and maintains an effective governance structure in ensuring the appropriate management of risks and level of internal controls (Mentel \& Brożyna, 2015). According to AlNajjar and Belghitar (2014), who examined whether good corporate governance mechanisms and performances are related to dividends, corporate governance practice in UK firms has an effect on the dividend payment. Although limited studies have been conducted on financial distress levels, similar to the above findings on firm performance, this study also projects the interaction effect on the level of financial distress. The following hypothesis is proposed:

H6: There are interaction effects between the MCCG and financial ratios of liquidity, leverage, profitability, performance, and dividend on financially distressed firms.

\section{METHODOLOGY}

This study uses data associated with all the companies listed on the main board of Bursa Malaysia with a total of 814 companies. After excluding the Banking and Financial Institution Industry, the sample is at 
796 companies. This study collected data for five years from 2010 to 2014 annual reports. After sifting out companies with incomplete data, approximately 741 companies were identified for the analysis. Since the current study was conducted in 2015, the use of the recent year, which was 2014, as the end of sample period, is reasonable to ensure that the data needed are available and sufficient for analysis purposes. It is believed that many firms are covered in this study since all sectors are taken into consideration. The data related to all the companies were collected from the Thomson DataStream and Thompson One Banker Database in Perpustakaan Abdul Razak 1 in UiTM Shah Alam.

The most popular method in measuring the financial conditions of a company is the Altman Z-Score. The Altman's Z-Score method was developed by Altman in 1968. It has been used to measure financial distress in several studies (Maina \& Sakwa, 2012; Kim-Soon et al., 2013). This model is a multivariate formula that has been used to measure the financial health of a company on whether it will enter into bankruptcy in the forthcoming two years. It analyzes the ratios of various bankrupt and non-bankrupt groups and studies the effect of using different combinations of financial ratios to predict business failures (Mohamed, 1997).

There are five independent variables under this model; each variable constitutes financial ratios and the rates recognized by the dependent variable (Z), which was developed to complement the model. According to Edward (1968), five financial analysis ratios have been used in the Altman model including earnings before interest and tax (ebit)/total assets ratio, sales/total assets ratio, market value of equity/total liabilities, working capital/total asset ratio, and retained earnings/total assets. Following Altman's (1968) study, the companies were classified into three groups according to their Z-score level. This is also supported by Demirkan and Platt (2009) in their study where they classified the financial conditions of a company that is being measured into three categories using the z-score. Companies which scored lower than 1.81 in the $z$ score are classified as a financially distressed company in contrast to other companies that would be classified as being financially healthy when their scores are higher than 2.67 or in the gray area when their scores are between the range of financially healthy and financially distressed. The descriptions of the categories of the three levels of financial distress are as follows;

Table 1

Description of Z-score

\begin{tabular}{|l|l|l|}
\hline No. & \multicolumn{1}{|c|}{ Range of Z-score } & \multicolumn{1}{c|}{ Interpretation } \\
\hline 1. & Above 2.99 & $\begin{array}{l}\text { The financial condition is in a good position and safe from } \\
\text { financial problems }\end{array}$ \\
\hline 2. & Between 2.99 and 1.81 & $\begin{array}{l}\text { It is considered the gray area as the financial condition has chances } \\
\text { of facing bankruptcy problems }\end{array}$ \\
\hline 3. & Less than 1.81 & $\begin{array}{l}\text { The financial condition is most likely heading towards bankruptcy } \\
\text { problems. Necessary actions are needed to avoid the worst } \\
\text { situations. }\end{array}$ \\
\hline
\end{tabular}

This study mainly uses the linear equation of the Altman Z-Score model. The linear equation of the Altman Z-Score is as follows:

$$
Z=0.012 X 1+0.014 X 2+0.033 X 3+0.006 X 4+0.999 X 5
$$

Where:

X1 - working capital/total assets 
Measures liquid assets in relation to the size of the company

$\mathrm{X} 2$ - retained earnings/total assets

Measures profitability that reflects the company's age and earning power

X3 - earnings before interest and taxes/total assets

Measures operating efficiency; apart from tax and leveraging factors, it recognizes operating earnings as being important to long-term viability

$\mathrm{X} 4$ - market value of equity/total liabilities

Adds market dimension that can show up security price fluctuation as a possible red flag

X5 - sales/total assets

For sales turnover (It measures revenue generating ability of a company's assets)

Z - overall index

The lower the company's Z-score, the bigher its probability to bankrupt.

\section{MEASUREMENT OF VARIABLES}

As Figure 1 shows, the framework of the current study contains six variables, which may influence financial distress (hypothesis of the study). These variables are measured by some specific measurements. Table 2 presents the measurements of the variables in the current study.

Table 2

Measurements of the variables

\begin{tabular}{|l|l|l|}
\hline \multicolumn{1}{|c|}{ Variables } & \multicolumn{1}{|c|}{ Measurement } & \multicolumn{1}{c|}{ Source } \\
\hline Liquidity & Current ratio $^{\mathrm{a}}$ & Rizwan Khurshid, 2013; Alifiah, 2014 \\
\hline Leverage & Debt ratio $^{\mathrm{b}}$ & $\begin{array}{l}\text { Ahmad Khaliq and Md Yousuf Harun, } \\
2014\end{array}$ \\
\hline Profitability & Profit marginc $^{\mathrm{c}}$ & $\begin{array}{l}\text { Becchetti and Sierra, 2003;Khurshid, } \\
2013\end{array}$ \\
\hline Firm's Performance & Tobin's Q ratio $^{\mathrm{d}}$ & Zunaidah and Fauzias, 2008 \\
\hline Dividend Policy & Dividend pay-out ratio $^{\mathrm{e}}$ & $\begin{array}{l}\text { Abreu \& Gulamhussen, 2013; Shisia, } \\
2014\end{array}$ \\
\hline $\begin{array}{l}\text { Malaysian Code on } \\
\text { Corporate Governance }\end{array}$ & MCCG $^{\mathrm{f}}$ & Bursa Malaysia \\
\hline
\end{tabular}

a. total current assets over total current liabilities

b. dividing total debt by total assets

c. net profit over total sales

d. ratio of the market value of a firm's assets (as measured by the market value of its outstanding stock and debt) to the replacement cost of the firm's assets

e. indicated in financial statement

f. Malaysian Code on Corporate Governance 2012 has been issued by Securities Commission in 2012 focusing on strengthening board structure and composition recognizing the role of directors as active and responsible fiduciaries

All the sample of data will be analyzed by using the Statistical Package for Social Science (SPSS) version 21 software. It will present the descriptive analysis, correlation, and regression analysis. 


\section{FINDINGS}

This section presents the results from the data analysis followed by a thorough discussion of the findings in the current study.

Table 3 below presents the summary of the statistics, which includes the minimum, maximum, mean, standard deviation, skewness, and kurtosis for all the variables used in this study.

Table 3

Results of the Descriptive Analysis

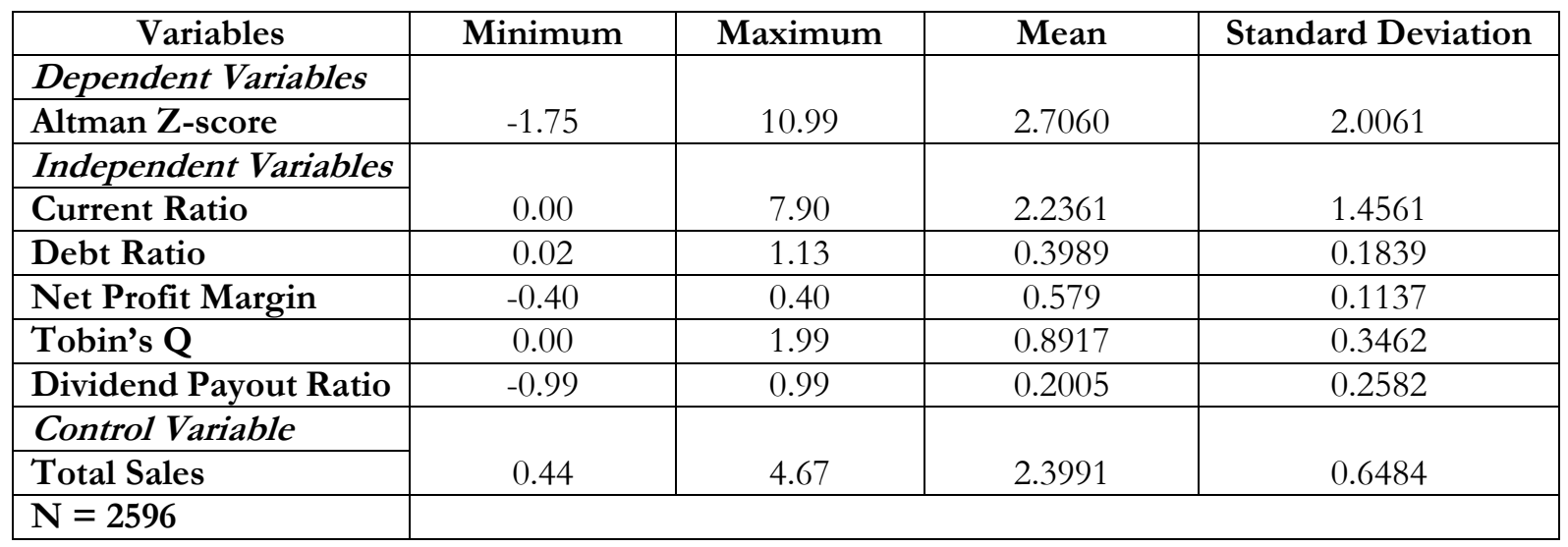

This table shows the summary of the descriptive statistics of the dependent, independent, and control variables used in this study.

Another test aimed at confirming that all the used data is normally distributed, is the normality test. Table 4 shows the result of this particular test.

Table 4

Summary of Result of the Normality Test

\begin{tabular}{|l|c|c|}
\hline \multicolumn{1}{|c|}{ Variables } & Skewness & Kurtosis \\
\cline { 1 - 1 } Dependent Variable & & \\
\cline { 1 - 1 } Altman Z-score & 1.2166 & 2.18 \\
\cline { 1 - 1 } Independent Variables & & \\
\cline { 1 - 2 } Current Ratio & 1.310 & 1.503 \\
\cline { 1 - 2 } Debt Ratio & 0.459 & -0.160 \\
\hline Net Profit Margin & -0.358 & 1.943 \\
\hline Tobin's Q & 0.685 & 0.724 \\
\hline Dividend Payout Ratio & 0.703 & 0.933 \\
\hline Control Variable & & 0.416 \\
\hline Total Sales & 0.420 & \\
\hline
\end{tabular}

After deleting the outliers, Table 3 presents the skewness and kurtosis values that provide information about the distribution shape of each variable. Majority of the variables have a positive skewness such as the Altman Z-Score, Current Ratio, Debt Ratio, Tobin's Q, Dividend Payout Ratio, and Total Asset. Only one variable shows a negative skewness value, which is the Net Profit Margin. However, the values of all 
variables are between the ranges of -1.96 to +1.96 . This means that all variables used in this study are normally distributed. For Kurtosis, the result reports that all variables used are normally distributed. The variables' values are between -2.00 and 2.00 and it is assumed that all variables are normally distributed and clustered in the centre.

In order to explain the strength and direction of the relationship between two variables in this study, a correlation analysis is done. Pearson's Correlation Analysis is used to explain this relationship (Neyman \& Pearson, 1938). The relationship must be in the range of -1.00 and 1.00. It is categorized into three categories. Table 5 below shows the summarized results of the correlation analysis.

Table 5

Results of correlation coefficient between DV with IV and CV

\begin{tabular}{|l|l|c|c|c|c|c|c|}
\hline \multicolumn{1}{|c|}{ Variables } & Z score & $\begin{array}{c}\text { Current } \\
\text { Ratio }\end{array}$ & $\begin{array}{c}\text { Debt } \\
\text { Ratio }\end{array}$ & $\begin{array}{c}\text { Net } \\
\text { Profit } \\
\text { Margin }\end{array}$ & $\begin{array}{c}\text { Tobin's } \\
\text { Q }\end{array}$ & $\begin{array}{c}\text { Dividend } \\
\text { Payout } \\
\text { Ratio }\end{array}$ & $\begin{array}{c}\text { LOG } \\
\text { TOTAL } \\
\text { SALES }\end{array}$ \\
\hline Z-score & - & $.486^{* *}$ & $-.568^{* *}$ & $.278^{* *}$ & $.157^{* *}$ & $.371^{* *}$ & $.158^{* *}$ \\
\hline Current Ratio & & - & $-.610^{* *}$ & $.161^{* *}$ & -0.023 & $.165^{* *}$ & $-.141^{* *}$ \\
\hline Debt Ratio & & & - & $-.159^{* *}$ & $.182^{* *}$ & $-.134^{* *}$ & $.263^{* *}$ \\
\hline Net Profit Margin & & & & - & $.051^{* *}$ & $.229^{* *}$ & $.092^{* *}$ \\
\hline Tobin's Q & & & & & - & $.145^{* *}$ & $.149^{* *}$ \\
\hline $\begin{array}{l}\text { Dividend Payout } \\
\text { Ratio }\end{array}$ & & & & & & & $.282^{* *}$ \\
\hline $\begin{array}{l}\text { LOG TOTAL } \\
\text { SALES }\end{array}$ & & & & & & & - \\
\hline
\end{tabular}

** Correlation is significant at the 0.01 level (2-tailed).

\subsection{Regression Analysis}

This section reports the testing results of the six (6) developed hypotheses. This is done by carrying out multiple regressions as an extension of the correlation analysis. Below is the model regressions employed for this study:

$$
\begin{aligned}
& F D=\beta_{0}+\beta_{1}(C U R R E N T \text { RATIO })+\beta_{2}(D E B T \text { RATIO })+\beta_{3}(N P \text { MARGIN }) \\
& +\beta_{4}(\text { TOBIN } Q)+\beta_{5}(D P R)+\beta_{6}(M C C G)+\beta_{7}(\text { LOG TOTAL SALES })+\varepsilon
\end{aligned}
$$

Where, $B_{0}=$ Intercept term

$B_{1}=$ current ratio

$B_{2}=$ Debt ratio

$B_{3}=$ Net Profit Margin

$B_{4}=$ Tobin's Q

$B_{5}=$ Dividend Payout Ratio

$B_{6}=$ Dummy variable (1) if the firm is in the year after implementation of MCCG, and 0 if the firm is in the year before implementation of MCCG, 2012.

$B_{7}=\log$ Total Sales

$\varepsilon=$ error terms

Table 6 shows the current ratio, debt ratio, net profit margin, Tobin's Q, and dividend payout ratio on the financial condition after controlling for the effect of total Sales (Log Total Sales). 
Multiple regression analysis

\begin{tabular}{|c|c|c|c|c|c|}
\hline \multirow[t]{2}{*}{ Model } & \multirow[t]{2}{*}{ Beta } & \multirow[t]{2}{*}{$\mathbf{t}$} & \multirow[t]{2}{*}{ Sig. } & \multicolumn{2}{|c|}{ Collinearity Statistics } \\
\hline & & & & Tolerance & VIF \\
\hline (Constant) & & 5.110 & .000 & & \\
\hline Current Ratio & .203 & 11.624 & .000 & .564 & 1.774 \\
\hline Debt Ratio & -.478 & -26.288 & .000 & .519 & 1.927 \\
\hline Net Profit Margin & .101 & 6.860 & .000 & .793 & 1.261 \\
\hline Tobin's Q & .217 & 15.890 & .000 & .918 & 1.089 \\
\hline $\begin{array}{l}\text { Dividend Payout } \\
\text { Ratio }\end{array}$ & .122 & 8.304 & .000 & .794 & 1.260 \\
\hline $\begin{array}{l}\text { LOG TOTAL } \\
\text { SALES }\end{array}$ & .260 & 17.685 & .000 & .792 & 1.263 \\
\hline MCCG & .018 & 1.373 & .170 & .995 & 1.005 \\
\hline
\end{tabular}

$\mathrm{R}^{2} 0.563$

F-Value 468

Df 7

Adjusted R ${ }^{2} 0.562$

Table 6 demonstrates that all independent variables are statistically significant at the level of $1 \%$. It shows that the financial ratio of liquidity, leverage, profitability, performance, and dividend ratio are significant in determining the financial distress levels. The entire hypotheses are accepted.

\subsection{INTERACTION EFFECTS OF FINANCIAL RATIOS WITH YEAR AFTER} MCCG

The current section presents the analysis of this effect on financial distress in Malaysia. Below is the model regression that includes the interactions of financial ratio and the MCCG towards financially distressed companies. Moderator is also treated as an independent variable before it is interacted with other independent variables.

$F D=\beta_{0}+\beta_{1}(C U R R E N T$ RATIO $)+\beta_{2}(D E B T$ RATIO $)+\beta_{3}(N P$ MARGIN $)$

$+\beta_{4}(T O B I N Q)+\beta_{5}(D P R)+\beta_{6}(M C C G)+\beta_{7}(C R x M C C G)+\beta_{8}(D E B T x M C C G)$

$+\beta_{9}(N P M x M C C G)+\beta_{10}(T Q x M C C G)+\beta_{11}(D P R x M C C G)+\beta_{12}($ LOG TOTALSALES $)+\varepsilon$

Where, $B_{0}=$ Intercept term

$B_{1}=$ current ratio

$B_{2}=$ Debt ratio

$B_{3}=$ Net Profit Margin

$B_{4}=$ Tobin's Q

$B_{5}=$ Dividend Payout Ratio

$B_{6}=$ Dummy variable (1) if the firm is in the year of after the implementation of MCCG, and 0 if firm is in the year before implementation of MCCG, 2012.

$B_{7}=$ Interaction between current ratio and MCCG

$B_{8}=$ Interaction between debt ratio and MCCG 
$B_{9}=$ Interaction between net profit margin and MCCG

$B_{10}=$ Interaction between Tobin's Q and MCCG

$B_{11}=$ Interaction between dividend payout ratio and MCCG

$B_{12}=\log$ Total Sales

$\varepsilon=$ error terms

Table 7 shows the interaction of the current ratio, debt ratio, net profit margin, Tobin's Q and Dividend Payout Ratio with the effect on the year of implementation of Malaysian Code on Corporate Governance (MCCG) for 2013 and 2014, on the Altman Z-score, which determines the probability of a company facing financial distress.

Table 7

Multiple regression analysis on interaction relationship

\begin{tabular}{|l|l|c|c|c|}
\hline \multicolumn{1}{|c|}{ Model } & Beta & t & Sig. \\
\hline 1 & (Constant) & & 3.697 & .000 \\
\hline & Current Ratio & .169 & 7.182 & .000 \\
\hline & Debt Ratio & -.480 & -19.792 & .000 \\
\hline & Net Profit Margin & .092 & 4.731 & .000 \\
\hline & Tobin's Q & .258 & 13.915 & .000 \\
\hline & Dividend Payout Ratio & .118 & 6.160 & .000 \\
\hline & LOG TOTAL SALES & .259 & 17.619 & .000 \\
\hline & MCCG & .067 & 1.038 & .300 \\
\hline & INT_CRxMCCG & .074 & 2.095 & .036 \\
\hline & INT_DEBTxMCCG & .002 & .041 & .967 \\
\hline & INT_NPMxMCCG & .017 & .859 & .391 \\
\hline & INT_TQxMCCG & -.131 & -3.297 & .001 \\
\hline & INT_DPRxMCCG & .007 & .317 & .751 \\
\hline
\end{tabular}

$\mathrm{R}^{2} \quad 0.567$

F-Value 227

Df 12

Adjusted R² 0.565

As Table 7 shows, two of the interactions, which are liquidity (current ratio) and firm's performance (Tobin's Q) after the year effect of MCCG, are significant to financial distress. The other interactions such as leverage (Debt Ratio), profitability (Net Profit Margin), and dividend (Dividend Payout Ratio) are not significant to the Altman Z-score. It means that these ratios do not have an impact in determining the probability of financial distress after the implementation of MCCG. The adjusted R squared for this study is 0.57 , which indicates that $57 \%$ of the variation in the financial condition can be explained by the interaction of the current ratio and the Tobin's Q after the implementation of MCCG.

\section{DISCUSSION}

The main objective of this study is to examine the relationships between external monitoring mechanisms and financially distressed companies in Malaysia. Based on the objective and sub-objectives of the study, six hypotheses were developed. 
The first hypothesis predicted that firms with lower liquidity would have a higher possibility of financial distress. According to Ahmad Khaliq and Md Yousuf Harun, (2014), liquidity is one of the important determinants in identifying financial distress among government linked companies in Malaysia. The financial condition of the company will rely on the level of liquidity of the company. As Table 6 shows, the regression result between the current ratio and the financial condition is measured using the Altman Z-score. A higher score indicates that the company is financially healthy. However, if the score is less than 1.81 , the company is classified as a financially distressed company. The result from the above table indicates that there is a significant relationship between liquidity and the Altman Z-score. This means the higher the liquidity of the company, the higher the score. Therefore, H1 is supported. Evidence shows that there is a positive relationship between liquidity and the Altman Z-Score among Malaysian Public Listed Companies in Bursa Malaysia.

The second hypothesis in this paper predicted that firms with higher leverage would have a higher possibility of financial distress. This is supported by the result of this study, which shows a significant negative relationship between debt ratio and Altman Z-score. It means that the higher the leverage of a company, the lower the Altman Z-score. It means that the possibility of a company moving towards financial distress is higher. Thus, consistent with Shamser et al. (2001), and Bhattacharjee and Han (2014), this regression results support the second hypothesis.

The third hypothesis assumed firms with lower net profit margin would have a higher possibility of financial distress. Based on the results in Table 6, there is a significant relationship between net profit margin and Altman Z-score. The higher the net profit margin, the higher the Altman Z-Score; thus, it reduces the possibility of a company turning into a financially distressed company. This is consistent with the research done by Geng, Bose, and Chen (2015), which indicates that the financial distress risk is high when the profitability is low. A low profitability is a signal of firm incapacity to convert revenue flow into profits. The higher the profitability, the lower the probability of financial distress. This result supports hypothesis 3.

The fourth hypothesis of this paper stated that firms with a lower Tobin's Q would have a higher possibility of financial distress. The regression in Table 6 demonstrates that the results of the Tobin's $Q$ are significant and indicate that the lower the Tobin's Q, the lower, the Altman Z-scores. A lower company performance indicates a lower financial health of the company. In other words, there is a high possibility of financial distress if there is poor performance in the company. Therefore, in line with Jahur and Quadir (2012), H4 is also supported.

Hypothesis 5 predicted that firms with a lower level of dividend would have a higher possibility of financial distress. The result of this study found that there is a significant relationship between dividend policy and the Altman Z-score. The higher the dividend payout ratio, the higher the Altman Z-score, thus, lowering the possibility of the company turning into a financially distressed company. Moreover, there is evidence among the public listed companies in Malaysia that an increase in the dividend payout ratio indicates a low possibility of bankruptcy. Therefore, similar to Malombe (2011) and Lundstrum and Miller (2010), this result supports hypothesis 5 .

The last hypothesis of the current research claimed that there is a significant interaction between the financial ratios (liquidity, leverage, profitability, performance and dividend) and the year after implementation of Malaysian Code on Corporate Governance (MCCG) with financial distress.

Many researchers have found a significant relationship between financial ratios and the code of best practices of corporate governance. Previous studies have found that liquidity, profitability, firm's performance, and dividend payment have a positive relationship with the effect of code of corporate governance practice (Al-Najjar \& Belghitar, 2014; Joh, 2003; Krafft et al., 2014; Prommin et al., 2014). On 
the other hand, leverage has a negative relationship with the effect of code of corporate governance practice (Arping \& Sautner, 2010). Due to this relationship between financial ratios with the effect of code of corporate governance practice in Malaysia and financial distress, this study suggested that there is significant interaction between financial ratios (liquidity, leverage, profitability, performance and dividend) and the effect of the implementation of MCCG with the financial distress level.

Even though it was found in the first regression that there was no significant value between MCCG and Altman Z-Score, the interaction of all financial ratios the year after implementation of Malaysian Code on Corporate Governance, revealed that only firm's performance (Tobin's Q) and liquidity (current ratio) have significant effects at $\mathrm{r}=0.01, \mathrm{p}<0.01$, and $\mathrm{r}=0.03, \mathrm{p}<0.01$, respectively. The other ratios such as debt ratio, net profit margin, and dividend are not significant given the interaction of financial ratio with the effect of after the implementation of MCCG. It means that the year after the implementation of MCCG interacted with firm's performance, and liquidity has a significant effect on the Altman Z-score. In other words, it is significant in determining the financial health of a firm.

Table 8

Summary of findings of the study

\begin{tabular}{|c|c|c|c|}
\hline & Research Hypothesis & Result & Hypotheses \\
\hline H1 & $\begin{array}{l}\text { Firms with lower liquidity would have a higher } \\
\text { possibility of financial distress }\end{array}$ & Significant & Supported \\
\hline $\mathrm{H} 2$ & $\begin{array}{l}\text { Firms with higher leverage would have a higher } \\
\text { possibility of financial distress }\end{array}$ & Significant & Supported \\
\hline H3 & $\begin{array}{l}\text { Firms with lower net profit margin would have a } \\
\text { higher possibility of financial distress. }\end{array}$ & Significant & Supported \\
\hline $\mathrm{H} 4$ & $\begin{array}{l}\text { Firms with lower Tobin's Q would have a higher } \\
\text { possibility of financial distress }\end{array}$ & Significant & Supported \\
\hline H5 & $\begin{array}{l}\text { Firms with a lower level of dividend would have a } \\
\text { higher possibility of financial distress }\end{array}$ & Significant & Supported \\
\hline \multirow[t]{2}{*}{ H6 } & \multirow{2}{*}{$\begin{array}{l}\text { There is a significant interaction between financial } \\
\text { ratios (liquidity, leverage, profitability, performance } \\
\text { and dividend), and year after implementation of } \\
\text { MCCG with financial distress. }\end{array}$} & $\begin{array}{l}\text { Significant (Liquidity } \\
\text { and Firm's } \\
\text { performance) }\end{array}$ & $\begin{array}{l}\text { Partially } \\
\text { Supported }\end{array}$ \\
\hline & & $\begin{array}{l}\text { Not Significant } \\
\text { (Leverage, } \\
\text { Profitability, } \\
\text { Dividend payout } \\
\text { ratio) }\end{array}$ & Not Supported \\
\hline
\end{tabular}

\section{CONCLUSION}

The current research aimed at determining the relationships between external monitoring mechanisms and financially distressed companies in Malaysia. In order to achieve this goal, data from 741 public listed companies in Malaysia from the year 2010 until 2015 were tested. The main structure of the research was based on six developed hypotheses.

The first hypothesis predicted that firms with lower liquidity would have a higher possibility of financial distress. This means that the lower the liquidity of a company, the higher the possibility of the company falling under financial distress. If the current ratio is high, it means that the firm is able to meet short-term obligations by using its current asset thus there will be less financial distress faced by the firm. It is important to investors, creditors as well as external regulators in monitoring the companies so that they do not turn 
into financially distressed companies. This result is consistent with studies by Ahmad Khaliq and Md Yousuf Harun (2014) and Sulaiman et al. (2001).

Second hypothesis predicted that the firms with higher leverage would have a higher possibility of financial distress. It means that the higher the leverage, the lower the Altman Z-score that increases the probability of a company turning towards financial distress. This finding is consistent with Ahmad Khaliq and Md Yousuf Harun (2014) and Vithessonthi and Tongurai (2015) who found that firms with a high leverage, increase their probability of facing financial distress.

Meanwhile, hypothesis 3 predicted firms with lower profitability would have a higher possibility of financial distress. This result is consistent with Geng et al. (2015) who stated that there is a high probability of financial distress if a firm has a lower profitability. This ratio gives significant information to investors, creditors and regulators, in determining the financial distress level.

Hypothesis 4 claimed firms with poor firm performance would have a higher possibility of financial distress. This means the lower the performance of the company, the higher the possibility of the firm facing financial distress and this is consistent with the studies by Delen et al. (2013) and Zeli (2014). They found that poor company performance might increase insolvency and bankruptcy risk among American and Italian firms.

Hypothesis 5 stated that firms with a lower level of dividend would have a higher possibility of financial distress. This result is consistent with Uwuigbei et al. (2012), who stated that there is a positive relationship between company performance and the dividend payout ratio in Nigeria. Thus, this study may help users in monitoring the level of financial distress among companies in Malaysia.

Hypothesis 6 predicted the interaction of Malaysian Code on Corporate Governance in Malaysia (MCCG) and liquidity, leverage, profitability, firm's performance, and dividend, on the financial distress levels. Based on Tables 6 and 7, this study found that Tobin's Q and the current ratio had significantly affected the financial distress level after the year of implementation of the MCCG in 2012. This means that with the recent effect of MCCG in 2012, it may strengthen these two ratios in determining the level of financial distress among companies in Malaysia. It shows that with the implication of code on corporate governance, it makes these two ratios have a stronger effect on determining the level of financial distress.

\section{FUTURE STUDY}

There are many possible opportunities for future studies to identify a significant relationship by extending to a larger sample size. It is recommended to extend the time frame to 10 years instead of 5 years to get a better view of the financial distress situation in Malaysia. This study can also be extended by focusing on individual industries among the public listed companies in Malaysia. This would assist in having more understanding about financial distress in each industry in Malaysia.

Future studies can also include different variables to be tested in determining the financial distress level among companies in Malaysia such as efficiency ratios, cash flow ratios, and market ratios. These added variables are useful to gain a deeper understanding and to give detailed information and explanation that can provide additional monitoring mechanisms for external users such as investors and creditors in making decisions.

\section{REFERENCES}

Abdul Rahman, A., Sulaiman, S., Fadel, E. S., \& Kazemian, S. (2016). Earnings Management and Fraudulent Financial Reporting: The Malaysian Story. Journal of Modern Accounting and Auditing, 12(2), 91-101. 
Abreu, J. F., \& Gulamhussen, M. A. (2013). Dividend payouts: Evidence from U.S. bank holding companies in the context of the financial crisis. Journal of Corporate Finance, 22, 54-65.

Khaliq, A., Altarturi, B. H. M., Thaker, H. M. T., Harun, M. Y., \& Nahar, N. (2014). Identifying Financial Distress Firms: A Case Study of Malaysia's Government Linked Companies (GLC). International Journal of Economics, Finance and Management, 3(3).

Al-Najjar, B., \& Belghitar, Y. (2014). Do Corporate Governance Mechanisms Affect Cash Dividends? An Empirical Investigation of UK Firms. International Review of Applied Economics, 28(4), 524-538.

Alifiah, M. N. (2014). Prediction of Financial Distress Companies in the Trading and Services Sector in Malaysia Using Macroeconomic Variables. Procedia - Social and Behavioral Sciences, 129, 90-98.

Altman, E. I. (1968). Financial ratios, discriminant analysis and the prediction of corporate bankruptcy. The Journal of Finance, 23(4), 589-609.

Amihud, Y., \& Mendelson, H. (1986). Asset pricing and the bid-ask spread. Journal of Financial Economics, 17(2), 223 249.

Arping, S., \& Sautner, Z. (2010). Corporate governance and leverage: Evidence from a natural experiment. Finance Research Letters, 7(2), 127-134

Baker, H. K., \& Haslem, J. A. (1973). Information needs of individual investors. Journal of Accountancy, November, 64-69.

Beaver, W. H. (1966). Financial ratios as predictors of failure. Journal of accounting research, 71-111.

Becchetti, L., \& Sierra, J. (2003). Bankruptcy risk and productive efficiency in manufacturing firms. Journal of Banking \& Finance, 27(11), 2099-2120.

Belás, J., Bartoš, P., Ključnikov, A., \& Doležal, J. (2015). Risk perception differences between micro-, small and medium enterprises. Journal of International Studies.

Bessler, W., \& Nohel, T. (1996). The stock-market reaction to dividend cuts and omissions by commercial banks. Journal of Banking \& Finance, 20(9), 1485-1508.

Betker, B. L. (1997). The Administrative Costs of Debt Restructurings: Some Recent Evidence. Financial Management, 26(4), 56-68

Bhattacharjee, A., \& Han, J. (2014). Financial distress of Chinese firms: Microeconomic, macroeconomic and institutional influences. China Economic Review, 30, 244-262.

Chan, K. C., \& Chen, N.-F. (1991). Structural and Returns Characteristics of Small the Journal of Finance, VOL. XLVI, NO. 4.

Chen, J., Marshall, B. R., Zhang, J., \& Ganesh, S. (2006). Financial Distress Prediction in China. Review of Pacific Basin Financial Markets and Policies, 9(2), 317-336.

Chen, Y., Weston, J. F., \& Altman, E. I. (1995). Financial distress and restructuring models. Financial Management, $57-$ 75.

Coffinet, J., Pop, A., \& Tiesset, M. (2013). Monitoring Financial Distress in a High-Stress Financial World: The Role of Option Prices as Bank Risk Metrics. Journal of Financial Services Research, 44(3), 229-257.

Cornell, B., \& Shapiro, A. C. (1987). Corporate stakeholders and corporate finance. Financial Management, 5-14.

Costea, C. D., \& Hostiuc, F. (2009). The Liquidity Ratios and Their Significance in the Financial Equilibrium of the Firms. The Annals of The "Ştefan cel Mare" University Suceava. Fascicle of the Faculty of Economics and Public Administration, 9(1).

Courtis, J. K. (1978). Modelling a Financial Ratio Categoric Framework. Journal of Business Finance \& Accounting, 5(4), 371-386.

Delen, D., Kuzey, C., \& Uyar, A. (2013). Measuring firm performance using financial ratios: A decision tree approach. Expert Systems with Applications, 40(10), 3970-3983.

Farinha, J., \& Moreira, J.A. (2007). Dividends and Earnings Quality: The Missing Link. cete. Faculty of economics, University of Porto. Retrieved June $10, \quad 2010$ from http://www.clsbe.lisboa.ucp.pt/resources/documents/professores/seminarios/Paper_21Jan2008.pdf

Fich, E. M., \& Slezak, S. L. (2008). Can Corporate Governance Save Distressed Firms from Bankruptcy? An Empirical Analysis. Review of Quantitative Finance and Accounting, 30(2), 225-251

Filbeck, G., \& Mullineaux, D. J. (1993). Regulatory monitoring and the impact of bank holding company dividend changes on equity returns. Financial Review, 28(3), 403-415. 
Geng, R., Bose, I., \& Chen, X. (2015). Prediction of financial distress: An empirical study of listed Chinese companies using data mining. European Journal of Operational Research, $241(1), 236-247$.

Kazemian, S., \& Sanusi, Z. M. (2015). Earnings Management and Ownership Structure. Procedia Economics and Finance, 31, 618-624.

Kim-Soon, N., Mohammed, A. A. E., \& Agob, F. K. M. (2013). A Study of Financial Distress Companies Listed in the Malaysian Stock Exchange using Financial Liquidity Ratios and Altman's Model. European Journal of Scientific Research, 114(4), 513-525.

Krafft, J., Qu, Y., Quatraro, F., \& Ravix, J.-L. (2014). Corporate Governance, Value and Performance of Firms: New Empirical Results on Convergence from a Large International Database. Industrial and Corporate Change, 23(2), 361-397.

Low, S.-W., Fauzias, M., \& Yatim, P. (2001). Predicting corporate financial distress using logit model: The case of Malaysia. Asian Academy of Management Journal, 6(1), 49-62.

Malombe, (2011). The effect of Dividend policy on profitability of Sacco's with Fosa's in Kenya. Unpublished MBA project. University of Nairobi.

Mentel, G., \& Brożyna, J. (2015). Compatibility of market risk measures. Journal of International Studies, 8(2), 52-62.

Mohamed Sadique, R. B., Roudaki, J., Clark, M. B., \& Alias, N. (2010). Corporate fraud: An analysis of Malaysian securities commission enforcement releases. World Academy of Science, Engineering and Technology, 42, 1199-1208.

Mohammed, M. (1997). Financial analysis. Amman, Jordan, Institute of banking studies.

Ong, S.-W., Yap, V. C., \& Khong, R. W. L. (2011). Corporate failure prediction. Managerial Finance, $37(6), 553$ - 564.

Pandey, I. M. (2001). Corporate Dividend Policy and Behaviour. Working Paper, No. 2001-11-01.

Neyman, J., \& Pearson, E. S. (1938). Contributions to the theory of testing statistical hypotheses: Printed in Great Britain by W. Lewis, MA, at the University Press.

Platt, S. D. H. (2009). Financial status, corporate governance quality, and the likelihood of managers using discretionary accruals. Accounting Research Journal, 22(2), 93-117.

Prommin, P., Jumreornvong, S., \& Jiraporn, P. (2014). The Effect of Corporate Governance on Stock Liquidity: The Case of Thailand. International Review of Economics and Finance, 32, 132-142.

Rashidah Abdul, R., \& Fairuzana Haneem Mohamed, A. (2006). Board, audit committee, culture and earnings management: Malaysian evidence. Managerial Auditing Journal, 21(7), 783-804.

Redding, L. S. (1997). Firm size and dividend payouts. Journal of Financial Intermediation, 6(3), 224-248.

Rumelt, R. P. (1974). Strategy, structure and economic performance. Cambridge, MA: Harvard University Press.

Shisia, A. (2014). Assessment of Dividend Policy on Financial. International Journal of Economics, Commerce and Management. Shumway, T. (2001). Forecasting Bankruptcy More Accurately: A Simple Hazard Model. Journal of Business, 74(1), 101.

Sulaiman, M. (2001). Predicting Corporate Failure in Malaysia. Asian Academy of Management Journal.

Sullivan, A., \& Sheffrin, S. M. (2003). Economics: Principles in action. Upper Saddle River, New Jersey 07458: Pearson Prentice Hall.

Uwuigbei, U., Jafaru, J., \& Ajayi, A. (2012). Dividend Policy and Firm Performance. Accounting and Management Information Systems, 11(3), 442-454.

Vithessonthi, C., \& Tongurai, J. (2015). The Effect of Firm Size on the Leverage-Performance Relationship during the Financial Crisis of 2007-2009. Journal of Multinational Financial Management, 29, 1-29.

Wahab, E. A. A., How, J. C. Y., \& Verhoeven, P. (2007). The Impact of the Malaysian Code on Corporate Governance: Compliance, Institutional Investors and Stock Performance. Journal of Contemporary Accounting \& Economics, 3(2), 106-129.

Ward, T. J., \& Foster, B. P. (1997). A note on selecting a response measure for financial distress. Journal of Business Finance \& Accounting, 24(6), 869-879.

Wu, D., Liang, L., \& Yang, Z. (2008). Analyzing the financial distress of Chinese public companies using probabilistic neural networks and multivariate discriminate analysis. Socio-Economic Planning Sciences, 42(3), 206-220.

Zeli, A. (2014). The financial distress indicators trend in Italy: an analysis of medium-size enterprises. Eurasian Economic Review, 4(2), 199-221.

Zunaidah, S., \& Fauzias, M.N. (2008). Dividends, Ownership Structure and Board Governance on Firm Value: Empirical Evidence from Malaysian Listed Firms. Malaysian Accounting Review, 7(2), 55-94. 